\title{
Analysis of Audit Competencies and Internal Control on Detecting Potential Fraud Occurrences
}

\author{
Mochammad Solichin ${ }^{1}$, Zuraidah Mohd. Sanusi ${ }^{2}$, Razana Juhaida Johari ${ }^{2, *}$, Tri Gunarsih ${ }^{1}$, \\ Nur Aima Shafie ${ }^{2}$ \\ ${ }^{1}$ Faculty of Business \& Humanities, Universitas Teknologi Yogyakarta, Indonesia \\ ${ }^{2}$ Accounting Research Institute, Faculty of Accountancy, Universiti Teknologi MARA, 40450 Shah Alam, Selangor, Malaysia \\ *Corresponding Author: razana@uitm.edu.my \\ Received September 11, 2021; Revised October 20, 2021; Accepted November 21, 2021
}

\begin{abstract}
Cite This Paper in the following Citation Styles
(a): [1] Mochammad Solichin, Zuraidah Mohd. Sanusi, Razana Juhaida Johari, Tri Gunarsih, Nur Aima Shafie, "Analysis of Audit Competencies and Internal Control on Detecting Potential Fraud Occurrences," Universal Journal of Accounting and Finance, Vol. 10, No. 1, pp. 171-180, 2022. DOI: 10.13189/ujaf.2022.100118.
\end{abstract}

(b): Mochammad Solichin, Zuraidah Mohd. Sanusi, Razana Juhaida Johari, Tri Gunarsih, Nur Aima Shafie (2022). Analysis of Audit Competencies and Internal Control on Detecting Potential Fraud Occurrences. Universal Journal of Accounting and Finance, 10(1), 171-180. DOI: 10.13189/ujaf.2022.100118.

Copyright $(2022$ by authors, all rights reserved. Authors agree that this article remains permanently open access under the terms of the Creative Commons Attribution License 4.0 International License

\begin{abstract}
It is stated that fraud in the government sector includes deceptive acts such as asset misappropriation, loss of state income, falsification of financial records and reports, and mark-ups in government financing. The purpose of this study is to investigate the potential impact of audit competences (professional skepticism and audit experience) and internal control on an auditor's capacity to detect potential fraud occurrences. Primary data were gathered via a printed questionnaire distributed to the 149 government auditors who work at Indonesia's Inspectorate Office. The findings, based on the Partial Least Squares of structural equation modelling, show that both audit competences have a significant impact on the capacity to detect probable fraud. Internal control, on the other hand, has no direct impact on the capacity to detect potential fraud. The findings show that internal control significantly moderates the link between audit competencies (professional skepticism and audit experience) and the auditor's ability to detect potential fraud occurrences. This research offers practical government suggestions for improving government auditors' professional audit competencies and abilities. Audit authorities should be able to create a more effective internal control structure that prioritizes feedback and learning. The limitations of the study as well as future research are highlighted.
\end{abstract}

Keywords Audit Competencies, Government Auditor, Professional Skepticism, Audit Experience, Internal Control, Fraud Occurrences

\section{Introduction}

Internal auditing in Indonesia has emphasized attention in response to public demands for accountability in government administration [1]. Four government agencies conduct internal audits: The Finance and Development Audit Agency (abbreviated as BPKP), the Inspectorate General, the Provincial Inspectorate, and the Regional Inspectorate (Government Regulation Number 60 of 2008). The four institutions serve as government auditors empowered by their primary responsibilities and functions [2]. Through audits, reviews, evaluations, monitoring, and other supervisory activities, government auditors monitor the management of state/regional finances. Government auditors' broad scope of supervision should be used to prevent irregularities in financial management within their scope of supervision [3].

For Indonesia, two monitoring mechanisms are in place: (i) external oversight by the Audit Board of the Republic of Indonesia and (ii) internal oversight by government auditors. These supervisory agencies are expected to mitigate the negative consequences of regional autonomy implementation, particularly in terms of fraud prevention. Fraud in government agencies does not always involve people in high positions; it is also possible for people in lower positions to commit fraud [4]. Typical forms of 
fraud include the manipulation of budget realisation records, the creation of forged documents, the overcharging of regional expenditures, the loss of regional revenues, and the misappropriation of regional assets [5]. Regrettably, fraud is still prevalent, particularly in local governments [6].

Indonesia is ranked 85 th out of 180 countries, with a score of 40 on the corruption perception index [7]. This datum demonstrates that Indonesia continues to face a significant corruption problem. This fact raises concerns about the role of government auditors in preventing and detecting potential fraud in government institutions. Numerous instances result in fraudulent acts that go unnoticed by government auditors. The BPK revealed 9,116 findings worth Rp10.35 trillion in the first semester of 2019 based on examination results as reported by the Audit Board of the Republic of Indonesia in 2019. These findings include issues with internal control, non-compliance with statutory requirements, and inefficiency, inefficiency, and ineffectiveness. These issues can result in state losses, potential losses, and potential revenue shortfalls.

According to Attribution Theory, a person's performance or ability is influenced by both individual and contextual factors. Internal control, as a situational factor, has the potential to alter how an individual performs a task [8]. Internal control, as defined by [9], is a process and procedure established by an organisation to monitor and control the behaviour of its members. However, a dearth of research has concentrated on audit competencies and internal control's ability to alter how an individual view and reacts to situations based on the information available. As a result, this study examines empirically how audit competencies (professional scepticism and professional experience) and internal control affect auditors' assessment of their ability to detect possible fraud.

This research contributes to the growing body of knowledge regarding auditors' ability to detect the possibility of fraud, particularly for government auditors. Additionally, this research provides insight into how local government management can strengthen the role of government auditors in supervising local financial management practises. The following section discusses the literature review and hypothesis development, research methods, results, and discussion, and concludes with a discussion of the research conclusions, as well as some limitations and recommendations for future research.

\section{Literature Review}

\subsection{Auditor's Judgement}

Judgment usually refers to forming ideas, opinions, or estimates about an object, event, state, or other types of the phenomenon [36]. An individual who performs a judgement may either be involved in an evaluation of a current state of affairs or predictions about the future [37]. The auditor must perform the assessment throughout the audit process. The accuracy of the auditor's assessment will affect the quality of the audit [10]. Judgment is the behavior of the decision-making process. When the auditor makes this assessment, he is fully aware that the results of his assessment will be reviewed and for information. Bonner [36] categorizes at least two main factors influencing auditor judgment (individual and environmental). Individual factors describe the characteristics of decision-makers that can affect the performance of tasks, for example, knowledge, experience, abilities, information processing abilities, and use of decision aids. Meanwhile, environmental factors relate to the circumstances and conditions around the individual when making judgments, for example, time pressure, accountability, incentives, and internal control [8]. Local government auditors are internal auditors who work in local government agencies and are responsible for ensuring that their financial management is free from fraud. As a result, government auditors must have the necessary individual skills to detect possible fraud.

\subsection{Professional Skepticism}

According to the Professional Standards for Public Accountants in Indonesia, professional scepticism is a mindset that asks questions and conducts a critical examination of audit evidence. Professional scepticism necessitates that auditors maintain an attitude that is perpetually sceptical, vigilant, and critical in all audit engagements. According to [11], professional scepticism refers to auditors' reluctance to accept management's assertions without corroborating evidence. Professional scepticism on the part of the auditor is critical when gathering audit evidence. Without professional scepticism, auditors will only discover inaccuracies caused by human error; it is much more difficult to discover inaccuracies caused by fraud [12].

The auditor must maintain a healthy scepticism and believe in the possibility of the client making material misstatements [13]. Auditors who are extremely sceptical will be able to persuade their statements, lowering the risk of failing to detect fraud [14]. Thus, with a professional scepticism, auditors will ask more investigative questions, critically analyse responses, and cautiously compare the results of the analysis to the evidence obtained. On the basis of these arguments, the following hypothesis is made:

H1: Professional skepticism has a positive effect on the auditor's ability to detect possible fraud occurrences.

\subsection{Audit Experience}

Johari et al. [15] noted that auditors' experience aids in 
their understanding of errors and fraud. Auditor with extensive experience detecting fraud will have an easier time detecting it than auditors with limited experience. Similar findings are found in the studies such as Anggriawan [16] and Kalbers and Fogarty [17], demonstrating that auditor experience enhances auditors' ability to detect fraud. On the basis of these arguments, the following hypothesis is made:

$\mathrm{H} 2$ : Audit experience has a positive effect on the auditor ability to detect possible fraud occurrences

\subsection{Internal Control}

Internal control is a component of a fraud protection system [18], which is designed by organisations to help in the early detection of fraud and to prevent irregularities. Internal control is modelled after a system that oversees an institution's accountability procedures. A strong internal control system will help to narrow or eliminate the possibility of fraud [19]. This has been demonstrated by prior research, which discovered that internal control functions in regulating human behaviour [20]. Internal controls should also be used to monitor those who exert influence over their behaviour toward the task at hand in order to detect possible fraud. Internal control is an external factor that can influence auditors' perceptions and reactions in a controlled manner, resulting in a more precise and well-ordered assessment in this case [21]. As a result, auditors are expected to act in accordance with their intentions in achieving organisational goals when it comes to internal controls. On the basis of these arguments, the following hypothesis is made:

H3: Internal controls positively influence on the auditor ability to detect possible fraud occurrences.

Curtis and Payne [9] defined internal control as "a process and procedure established by an organisation to monitor and manage its members' behaviour." It is a contextual factor that can affect an internal auditor's ability to detect potential fraud, as well as the manner in which a person performs assigned tasks, thereby impairing the achievement of these tasks due to its moderating effect [8]. Internal controls that are effective will enable auditors with a high level of audit competency (professional scepticism and audit experience) to improve their ability to detect the possibility of fraud. Similarly, auditors with limited audit competencies may be able to detect the possibility of fraud as a result of robust policies and internal control systems. Only auditors with audit competencies (professional scepticism and audit experience) can have an effect on an auditor's ability to detect possible fraud in a low internal control environment On the basis of these arguments, the following hypothesis is made:

H4a: Internal control is positively moderated the relationship between professional skepticism and the auditor ability to detect possible fraud occurrences.
H4b: Internal control is positively moderated the relationship between audit experience and the auditor ability to detect possible fraud occurrences.

\section{Methodology}

\subsection{Sample Selection}

The population in this study is the Government Internal Supervisory Apparatus who work at local government in Indonesia as government auditor. Based on data from the Central Statistics Agency, the number of local governments in Indonesia is 514, consisting of 416 districts and 98 cities (BPS, 2017). The sample for this study was selected using the purposive sampling technique. The consideration used is that government auditor works for the local government with the criteria that the financial statements (LKPD) obtained an unqualified opinion or a qualified opinion from the Supreme Audit Agency. This criterion ensures that the government auditors, as the government's internal auditors, have played a role in carrying out their duties properly [35].

\subsection{Data Collection}

This study is quantitatively designed to test hypotheses using primary data obtained through a questionnaire survey. The survey was carried out with the use of a printed questionnaire. Questionnaires were distributed directly to selected local governments that were geographically close. In addition, the questionnaires were also distributed indirectly via email through intermediaries in selected local governments to be delivered to respondents. Before the questionnaires were distributed, a pilot test was conducted involving 30 bachelor students. The purpose of this trial was to obtain feedback on the understanding, content and relevance of the questions in the questionnaire from the point of view of actual respondents [38]. Overall, 30 respondents reported that the constructs in the questionnaire could be understood and they successfully answered the questionnaire within the allotted time.

\subsection{Measurement of Variables}

All factors were scored on a Likert scale of 1-7, one representing strongly disagree and seven representing strongly agree. The application of the seven-point Likert scale in this study was to increase the variance in the measure and maximized the reliability and construct validity [39]. The dependent variable in this study is the ability of government auditors on duty in local governments to detect the possibility of fraud. They are judged on their ability to discover or identify the existence and reality of cash shortages or misappropriation of assets 
as a result of lawlessness or willful lawlessness. The ability to detect fraud was measured by a questionnaire referring to the study of Fullerton and Durtschi [22]. The following are the three independent variables:

i. Professional skepticism is the auditor's attitude to always question and critically evaluate evidence in carrying out an audit engagement. The variable of professional skepticism was measured by a questionnaire that referred to Hurtt's study [23]. Audit experience is a process of learning and increasing development and knowledge, both formal and non-formal.

ii. Audit experience is seen as an important factor in predicting and assessing auditors' performance in conducting audits. Indicators of audit experience are referenced from research by Kalbers and Fogarty [17]. This indicator is the length of time he has served as an auditor and the number of assignments he has handled.

iii. The internal control is a process designed and carried out by the leadership and all employees to provide adequate confidence in achieving organizational goals by implementing programs and activities efficiently and effectively, the reliability of financial reports, and compliance with applicable laws. The internal control system is measured by questionnaire that refers to Wilopo's research [24].

\subsection{Data Analysis}

The data analysis technique in this study used Partial Least Squares-Structural Equation Modeling (PLS-SEM). PLS testing is carried out in two stages, namely evaluating the measurement model (outer model) and evaluating the structural model (inner model). Evaluation of the measurement model is used to assess the reliability and validity of the items in measuring the construct. The reliability and validity of the measurement model need to be checked before the structural model assessment is carried out to ensure that the measurements represent the constructs within the research framework, while the evaluation of the measurement model is used to evaluate the coefficient of determination $\left(\mathrm{R}^{2}\right)$ and evaluate the significance relationship [25].

\section{Findings and Discussion}

\subsection{Profile of Respondents}

Only 164 replies were obtained out of 300 questionnaires given to participants. Due to incomplete completion, 15 replies were removed, leaving 149 responses for analysis. The overall rate of return for this research was $49.7 \%$. Out of 149 respondents consist of $42 \%$ female respondents and $58 \%$ of male respondents. The majority of respondents (36\%) were between the ages of 30 and 40 , with $34 \%$ being above the age of 40 and just $30 \%$ being under the age of 30 . Then based on education respondent, there are $61 \%$ have a bachelor's degree, $28 \%$ have a diploma, and just $11 \%$ have a master's degree. The respondents are divided into four groups: junior auditors (46.6\%), senior auditors (23.6\%), audit managers $(16.2 \%)$, and audit partners (13.5\%).The majority of respondents, $56 \%$ had worked as an internal auditor in government organisations for more than ten years.

\subsection{Common Method Variance (CMV)}

To determine the normality of the data, this study used the skewness and kurtosis tests and discovered that the data are normally distributed. According to Hair et al., [25], a common method variance (CMV) is a concern in social sciences research when using single source data. Thus, a single factor analysis is used to confirm that CMV is not a problem with this dataset. The results indicate that a single factor explains only $44 \%$ of the variance, which is less than $50 \%$, indicating that no CMV was present in the data.

\subsection{Assessment of the Measurement Model}

The convergent validity test results in this study are shown by comparing the research model's parameters from the loading factor value and the Average Variance Extracted (AVE) value in the model. The loading factor values are shown in Table 1, while the Average Variance Extracted (AVE) values are shown in Table 2. 
Table 1. Outer Loadings of Constructs

\begin{tabular}{cccccccc}
\hline Items & OL & Items & OL & Items & OL & Items & OL \\
\hline Ability to detect potential fraud & \multicolumn{1}{c}{ Professional Skepticism } & Audit Experience & \multicolumn{2}{c}{ Internal Control System } \\
\hline DoF1 & 0.858 & Skep1 & 0.735 & Exp1 & 0.684 & IC1 & 0.747 \\
DoF2 & 0.724 & Skep2 & 0.754 & Exp2 & 0.671 & IC2 & 0.767 \\
DoF3 & 0.721 & Skep3 & 0.697 & Exp3 & 0.734 & IC3 & 0.819 \\
DoF4 & 0.626 & Skep4 & 0.699 & Exp4 & 0.688 & IC4 & 0.798 \\
DoF5 & 0.750 & Skep5 & 0.605 & Exp5 & 0.826 & IC5 & 0.710 \\
DoF6 & 0.858 & Skep6 & 0.736 & Exp6 & 0.783 & IC6 & 0.784 \\
DoF7 & 0.863 & Skep7 & 0.799 & Exp7 & 0.818 & IC7 & 0.764 \\
DoF8 & 0.750 & Skep8 & 0.716 & & & IC8 & 0.643 \\
DoF9 & 0.722 & Skep9 & 0.689 & & & IC9 & 0.601 \\
DoF10 & 0.637 & Skep10 & 0.605 & & & & \\
DoF11 & 0.718 & Skep11 & 0.757 & & & & \\
DoF12 & 0.867 & Skep12 & 0.792 & & & & \\
\hline
\end{tabular}

Table 2. Average Variance Extracted (AVE)

\begin{tabular}{cc}
\hline Constructs & AVE \\
\hline Ability to detect possible fraud occurrences & 0.581 \\
Audit Experience & 0.556 \\
Internal Control System & 0.548 \\
Professional Skepticism & 0.515 \\
\hline
\end{tabular}

Table 3. Reflective Discriminant Validity

\begin{tabular}{cccccc}
\hline No. & Constructs & $\mathbf{1}$ & $\mathbf{2}$ & $\mathbf{3}$ & $\mathbf{4}$ \\
\hline 1 & Detecting potential fraud occurrences & 0.762 & & & \\
2 & Audit Experience & 0.657 & 0.746 & & \\
3 & Internal Control System & 0.687 & 0.668 & 0.740 & 0.718 \\
4 & Professional Skepticism & 0.701 & 0.659 & 0.625 & \\
\hline
\end{tabular}

As illustrated in Table 1, the loading factor value for all indicators is greater than 0.6 . Thus, they complied with Hair et al., [25] requirements for factor loading. Then, as shown in Table 2, the AVE value for all constructs is greater than 0.50. This demonstrates that the AVE parameter's rule of thumb has also been followed. As a result, all constructs are determined to be valid. The fact that the outer loading and AVE parameters are satisfied indicates that the research model is adequate and passes the convergent validity test.

Next, the discriminant validity test was conducted using the Fornell-Larker criterion, which states that the variance shared by each construct and its indicator must be greater than the variance shared by all other constructs [25]. According to Table 3 , the results indicate that all diagonal elements in each row and column are greater than the off-diagonal correlation. As a result, discriminant validity can be supported at the construct level.

The rule of thumb used to assess construct reliability is to see that the composite reliability value must be greater than 0.7 [25]. Based on Table 4 below, it can be seen that the overall composite reliability value has a value above 0.70 , so it can be concluded that the indicators used in this study have met the criteria for good reliability.

Table 4. Construct Reliability

\begin{tabular}{ccc}
\hline No. & Constructs & $\begin{array}{c}\text { Composite } \\
\text { Reliability }\end{array}$ \\
\hline 1. & Ability to detect potential fraud & 0.943 \\
occurrences & 0.897 \\
3. & Audit Experience & 0.915 \\
4. & Internal Control System & 0.927 \\
\hline
\end{tabular}

\subsection{Assessment of the Structural Model}

In this study, the R-squared value of 0.784 indicates that all constructs together can account for 78.4 percent of the auditor's ability to detect fraud. While additional variables not included in the research model account for the remaining 21.6 percent. In the field of behavioral research, R-squared values greater than 0.20 are considered very acceptable [25]. 
Table 5. Results of Bootstrapping for Assessment of Path Coefficients

\begin{tabular}{cccccc}
\hline $\begin{array}{c}\text { Hypo- } \\
\text { thesis }\end{array}$ & Path Relationship & $\boldsymbol{\beta}$ & Mean & T-Stat & P- Values \\
\hline H1 & Skep -> DoF & 0.555 & 0.625 & 3.466 & 0.001 \\
H2 & Exp -> DoF & 0.387 & 0.319 & 2.464 & 0.014 \\
H3 & IC -> DoF & 0.016 & 0.013 & 0.53 & 0.596 \\
H4a & IC*Skep -> DoF & 0.164 & 0.162 & 2.372 & 0.018 \\
H4b & IC*Exp -> DoF & 0.163 & 0.163 & 2.199 & 0.028 \\
\hline
\end{tabular}

The results of the bootstrap procedure performed in Smart PLS are presented in Table 5, which includes the path coefficient for the structural model, the standard deviation, the T-statistic value, and the significance of the results at the $5 \%$ level.

According to Table 5, the four hypotheses $\mathrm{H} 1$ (p-value $=0.001), \mathrm{H} 2(\mathrm{p}$-value $=0.014), \mathrm{H} 4 \mathrm{a}(\mathrm{p}$-value $=0.018)$, and $\mathrm{H} 4 \mathrm{~b}$ (p-value $=0.028)$ all demonstrate significant results, indicating that they are all supported. Meanwhile, hypothesis $\mathrm{H} 3$ has a statistically insignificant coefficient with a $\mathrm{p}$-value greater than 0.05 ( $\mathrm{p}$-value $=0.596)$. As a result, hypothesis $\mathrm{H} 3$ is not supported.

\section{Discussion of the Findings}

For hypothesis H1, it was discovered that professional scepticism significantly impairs government auditors' ability to detect potential fraud occurrences. It can be concluded that the ability of government auditors to detect the possibility of fraud varies significantly depending on their level of scepticism. This implies that government auditors will be more effective at detecting fraud if they maintain a healthy scepticism. The significance of this finding could be attributed to the role of government auditors' scepticism. This finding suggests that government auditors should arm themselves with a healthy dose of scepticism to aid in performance improvement. This finding is consistent with Popova's study [26], which discovered that professional scepticism can improve an auditor's judgement in certain situations, depending on the nature and duration of the task at hand.

Additionally, the Indonesian State Financial Audit Standards (SPKN) state that auditors must consider the risk of fraud that could affect the audit results. As a result, the auditor should exercise professional scepticism in assessing those risks in order to ascertain the risks that could jeopardise the audit work if fraud occurred or could have occurred.

The results of the second hypothesis test indicate that audit experience has a significant positive effect on auditors' ability to detect possible fraud. These findings suggest that an auditor's experience can influence his or her ability to detect possible fraud. This indicates that experienced auditors will have a greater understanding of errors and fraud, which will aid them in evaluating audit evidence and thereby improving their performance, including detecting the possibility of fraud. Mohd-Sanusi et al. [27] and Herliansyah and Ilyas [28] stated that experience is critical for auditors because it assists auditors in identifying fraudulent activities during the audit. An experienced auditor will assist the auditor in comprehending, detecting, and even locating the source of the fraud. This is understandable given the auditor's prior experience. The findings of this study corroborate prior research such as Johari et al. [15], Kiswanto and Maulana [29] as well as Knapp and Knapp [30], all of which demonstrate that audit experience has a beneficial effect on auditors' ability to detect fraud.

The third hypothesis test asserts that internal controls have a significant impact on auditors' ability to detect potential fraud. This hypothesis is found to be unsupported. The findings of this study indicate that internal control has no direct effect on auditors' ability to detect possible fraud ( $\mathrm{p}$-value> 0.05). This finding contradicts prior researches indicating that internal control is a factor affecting performance proved by Jones [31] and Florio and Leoni [32]. This finding is likely due to the fact that internal control is primarily implemented at the organisational level in local governments, rather than at the activity level. This is because the internal control system is viewed as a formal control at the organisational level that ensures programmes and activities run smoothly, efficiently, effectively, and economically, while safeguarding resources against misuse, waste, errors, and fraud [33].

The results of the moderation test for hypothesis H4a indicate that internal control has a moderating effect on the relationship between professional scepticism and auditors' ability to detect the possibility of fraud (p-value $=0.018$ ). These findings suggest that internal control interacts with the sceptical attitude of government auditors to forecast the possibility of fraud. This means that the existence of an internal control system has an effect on the relationship between professional scepticism and the ability of government auditors to detect the possibility of fraud. Internal control, in its current state, does not impair government auditors' ability to detect possible fraud, as hypothesis $\mathrm{H} 3$ indicates. These findings suggest the existence of a contrast effect when confronted with professional scepticism.

Similar findings were obtained from the $\mathrm{H} 4 \mathrm{~b}$ 
hypothesis test, which indicates that internal control systems have a positive effect on the relationship between audit experience and the ability of government auditors to detect possible fraud. The results of the hypothesis test indicate a significant effect ( $\mathrm{p}$-value 0.05 ), indicating that the $\mathrm{H} 4 \mathrm{~b}$ hypothesis is supported. These findings corroborate Choi et al. [20], who demonstrate that experienced employees are unconcerned about being controlled in their behaviour because they know they will always do their best within their capabilities. However, inexperienced employees will become uncomfortable when they are controlled and will perceive internal control as a hindrance to their work. Additionally, the findings of this study corroborate [33] and [34] who assert that people will perceive internal control as a beneficial mechanism for preventing deviant behaviour and thereby achieving higher performance results.

\section{Conclusions}

The purpose of this study is to determine the extent to which auditors' competencies and internal controls influence their success or failure in detecting fraud. The findings indicate that two competencies, professional skepticism and audit experience, had a significant effect on government auditors' ability to detect possible frauds. Meanwhile, internal control has no effect on the government's or auditors' ability to detect potential fraud. While internal control has no direct effect, it was discovered that it significantly modifies the relationship between competencies (professional scepticism and audit experience) and the ability to detect the possibility of fraud.

Internal control, according to the American Institute of Certified Public Accountants, is critical for protecting entities against human weakness and minimising the possibility of errors or actions that are inconsistent with the rules. This study makes a number of theoretical and practical recommendations. To begin, these findings are consistent with the attribution theory, which states that both internal and external factors influence the auditor's assessment of the possibility of fraud.

Environmental factors, in this case internal control, are external influences that have the potential to influence an individual's interactive judgement. Second, professional scepticism and audit experience are critical internal indicators of fraud detection. Third, internal control as an external factor has the potential to strengthen the link between internal factors and the ability to detect potential fraud occurrences. Finally, government auditors should educate their staff to be more sceptical and provide opportunities for development. This finding is consistent with attribution theory, which recognises that environmental factors, in this case internal control, are external influences that can influence a person's judgement in an interactive manner.

This study takes a quantitative approach, collecting data via a questionnaire that might constrain the study's generalizability. Thus, future researches can be conducted using a mixed methods approach that incorporates quantitative and qualitative research methods in order to examine the effect of various factors on the detection of fraud.

\section{APPENDIX: RESEARCH INSTRUMENT}

\section{DETECTING POTENTIAL FRAUD OCCURRENCES}

1. One of the causes of fraud is authoritarian leadership.

2. Employees who complain of the grounds of discrimination deserve attention.

3. The intense job competition in the department or division I am auditing is an indication of fraud.

4. If the accounting department keeps many adjusting entries a week before the auditor arrives, this is a sign of fraud.

5. The write-off of large amounts of accounts receivable is an indication of fraud.

6. One sign of fraud is the absence of supporting evidence for certain transactions.

7. An employee who has an odd job to earn extra money tends to commit fraud.

8. An employee who thinks that his work cannot be completed on time is more prone to fraud.

9. An employee who refuses to take leave is an indication of fraud.

10. A leader who entrusts all of the bookkeeping to an employee because the employee has been doing his job for ten years is easier to commit fraud.

11. Employees who complain that their boss's salary is too much have a greater tendency to commit fraud.

12. An employee who complains that the entity's policies are unfair is one possibility of fraud.

\section{SKEPTISME PROFESSIONAL}

1. The auditor must be able to reject a statement or statement without clear evidence.

2. The auditor will ask many questions to prove a certain object to other auditors.

3. The auditor must have a skeptical attitude not to rush the decision making process.

4. The auditor will not make a decision if all the information is not valid.

5. Auditors who have a skeptical attitude will feel happy when they find new information.

6. Auditors who have a skeptical attitude will not make a decision if all the information has not been revealed. 
7. Auditors who have a skeptical attitude try to understand the behavior of others.

8. Auditors who have a skeptical attitude try to understand the behavior of others.

9. Auditors who have a skeptical attitude are able to make decisions and argue to correct the opinions of others.

10. Auditors who have a skeptical attitude are able to solve inconsistent information.

11. Auditors who have a skeptical attitude must have a confident attitude in interacting with clients.

12. Auditors who have a skeptical attitude do not immediately accept or justify statements from others.

13. Auditors who have a skeptical attitude must be objective in concluding the evidence so that it can support the decision-making process.

\section{AUDIT EXPERIENCE}

1. I have audited many clients, so I understand better how to deal with an inspection entity/object.

2. I have audited various types of entity characteristics.

3. I have completed various types of examination assignments.

4. The more entities that are examined, the better my examination results will be.

5. I have been auditing for a long time.

6. The length of time working as an auditor can affect whether the examination is good or not.

7. The length of time I worked as an auditor has affected the timeliness of completing the audit.

\section{INTERNAL CONTROL SYSTEM}

1. Local governments have emphasized integrity and ethical values to employees.

2. The local government organizational structure has described the main tasks, functions, responsibilities and authorities for each work unit.

3. The identified risks are sorted, minimized and communicated with staff or employees.

4. There have been actions regarding attitudes in assessing the risks faced by local governments.

5. Local government checks and records and monitors the achievement of local government against plans made in accordance with existing mechanisms and there is a separation of duties and responsibilities according to functions

6. Documentation of transactions and other important activities has been carried out thoroughly and accurately

7. Reports are made on time and well prepared and reported in writing to the authorized party in authorizing.
8. Recommendations for improving the internal control structure have been implemented and monitored by the local government.

9. Local Governments conduct separate evaluations and take follow-up actions to resolve problems with audit findings.

\section{REFERENCES}

[1] Kharisma B., "Good Governance Sebagai Suatu Konsep dan Mengapa Penting dalam Sektor Publik dan Swasta: Suatu Pendekatan Ekonomi Kelembagaan," Buletin Studi Ekonomi, Vol. 19, No.1, pp. 9-30, 2014. DOI:10.24843/BSE.2014.v25.i01.p02

[2] Djanegara MS., "BPK Ungkap 9.116 Temuan Pada Penyerahan IHPS I 2019," Badan Pemeriksa Keuangan Republik Indonesia, 2019. https://www.bpk.go.id/news/bp k-ungkap-9116-temuan-pada-penyerahan-ihps-i-2019

[3] Lediastuti, D., and Subandijo U., “Audit Forensik Terhadap Pengelolaan dan Pertanggungjawaban Keuangan Negara (Studi Kasus Pada Badan Pemeriksa Keuangan RI),” Jurnal Magister Akuntasi Trisakti, Vol. 1 No.1, pp. 89-108, 2014. https://www.trijurnal.lemlit.trisakti.ac.id/jmat/article/view/ 4933

[4] Burhanuddin, "Tindak Pidana Korupsi Sebagai Kejahatan Korporas," Jurnal Cita Hukum, Vol. 1, No. 1, 2013 pp. 75-84. DOI: $10.15408 /$ jch.v1i1.2981

[5] Hasfi N., Martoyo, Haryono D., "Pengelolaan Barang Milik Daerah (Studi pada Dinas Pendapatan, Pengelolaan Keuangan dan Aset Kabupaten Sintang," Jurnal Tesis PMIS-UNTAN-PSIAN, 2013. https://jurnal.untan. ac.id/index.php/jpmis/index

[6] Suryana, A., Sadeli D., "Analisis Faktor-Faktor Yang Mempengaruhi Terjadinya Fraud," Jurnal Riset Akuntansi dan Perpajakan, Vol. 2, No. 2, pp. 127-138, 2017. DOI: 10.35838/jrap.2015.002.02.12

[7] Trisasongko D., "Corruption Perceptions Index 2019," Transparancy International Indonesia, 2020. https://riset.ti.or.id/corruption-percep-tions-index-2019/

[8] Mala R., Chand P., "Judgment and Decision-Making Research in Auditing and Accounting: Future Research Implications of Person, Task, and Environment Perspective," Accounting Perspectives, Vol. 14, No.1 pp. 1-50, 2015. https://doi.org/10.1111/1911-3838.12040

[9] Curtis M. B., \& Payne E. A., "Modeling Voluntary CAAT Utilization Decisions in Auditing," Managerial Auditing Journal, Vol. 29, No. 4, pp. 304-326, 2014. https://doi.org/ 10.1108/MAJ-07-2013-0903

[10] Carpenter T. D., Durtschi C., Gaynor L. M., "The Incremental Benefits of a Forensic Accounting Course on Skepticism and Fraud-Related Judgments," Issues in Accounting Education, Vol. 26, No. 1, pp. 1-21, 2011. https://doi.org/10.2308/iace.2011.26.1.1 
[11] Julian L., Johari R. J., Said J., Wondabio L.S., "The Effects of Tone at the Top and Professional Skepticism on Fraud Risk Judgment among Internal Auditors in Indonesia," Management and Accounting Review (MAR), Vol. 20, No. 1, pp. 139-153, 2021. http://ir.uitm.edu.my/id/eprint/47758/ 1/47758.pdf

[12] Wiguna F., Hapsari D.W., "Influence of Professional Skepticism and Independence of the Auditor on Fraud Detection," e-Proceeding of Management, Vol. 2, o. 1, pp. 453-461, 2015.https://openlibrarypublica-tions.telkomuniv ersity.ac.id/index.php/management/article/view/1746

[13] Liburd H.L., Cohen J.R., Trompeter G., "Effect of Earning Forecasts and Heightened Professional Skepticism on the Outcomes of Client-Auditor negotiation, "Journal of Business Ethics, Vol. 116, No. 2, pp. 311-325, 2013. DOI: 10.1007/s10551-012-1473-5

[14] Mapuasari, S.A., "The Ethics of Professional Skepticism: A Study in Indonesia Supreme Audit Institution," Journal of Aplied Accounting and Science, Vol. 1, No. 1, pp. 1-11, 2017.http://e-journal.president.ac.id/presunivojs/index.php /JAAF/article/view/356/201

[15] Johari R.J., Alam M.M., Said J., "Investigating Factors that Influence Malaysian Auditors Ethical Sensitivity," International Journal of Ethics and Systems, Vol. 37 No. 3, 406-421, 2021. https://doi.org/10.1108/IJOES-01-2021 $-0006$

[16] Anggriawan E. F., "Pengaruh Pengalaman Kerja, Skeptisme Profesional dan Tekanan Waktu terhadap Kemampuan Auditor Dalam Mendeteksi Fraud (Studi Empiris pada Kantor Akuntan Publik di DIY)," Nominal Barometer Riset Akuntansi dan Manajemen, Vol. 3 No. 2, pp. 101-116, 2014. https://doi.org/10.21831/nominal.v3i2. 2697

[17] Kalbers L. P., Fogarty T. J., "Antecedents to Internal Auditor Burnout," Journal of Managerial Issues, Vol.17, No.1, 101-118, 2005.https://www.jstor.org/stable/4060447

[18] Rae K., Subramaniam N., "Quality of Internal Control Procedures: Antecedents and Moderating Effect on Organizational Justice and Employee Fraud," Managerial Auditing Journal, Vol. 23 No. 2, pp. 104-124, 2008. DOI:10.1108/02686900810839820.

[19] Mahadeen B., Al-Dmour R.H., Obeidat B.Y., Tarhini A., "Examining the effect of the organization's internal control system on organizational effectiveness: A Jordanian empirical study," International Journal of Business Administration, Vol. 7 No. 6, pp. 22-31, 2016 DOI:10.5430/ijba.v7n6p22

[20] Choi J. H., Choi S., Hogan C.E., Lee J., "The Effect of Human Resource Investment in Internal Control on the Disclosure of Internal Control Weaknesses," Auditing: A Journal of Practice and Theory, Vol. 32, No. 4, pp. 169-199, 2013. https://doi.org/10.2308/ajpt-50514

[21] Cardona R.J., Figueroa C.B.F., "Does Experience Affect Auditors' Professional Judgement? Evidence from Puerto Rico," Accounting \& Taxation, Vol. 5, No. 2, pp. 13-32, 2013. https://ssrn.com/abstract $=2323649$

[22] Fullerton R., Durtschi C., "The Effect of Professional Skepticism on the Fraud Detection Skills of Internal
Auditors," SSRN Electronic Journal, Working Paper, 2004. DOI:10.2139/ssrn.617062

[23] Hurtt, R.K., "Development of a Scale to Measure Professional Skepticism," Auditing: A Journal of Practice \& Theory, Vol. 29, No. 1, pp. 149-171, 2010. DOI: 10.2308/ aud.2010.29.1.149

[24] Wilopo W., "Analisis Faktor-Faktor Yang Berpengaruh terhadap Kecenderungan Kecurangan Akuntansi: Studi Pada Perusahaan Publik dan Badan Usaha Milik Negara di Indonesia," The Indonesian Journal of Accounting Research, Vol. 9, No. 3, 2006. DOI: http://doi.org/10.3331 2/ijar. 163

[25] Hair J. F., Hult G.T.M., Ringle C.M., Sarstedt M, "Assessing PLS-SEM Results Part III: Evaluation of the Structural Model," A Primer of Partial Least Squares Structural Equation Modelling (PLS-SEM) 2nd edition, Sage Publications, Inc., United Kingdom, London, 2014, pp. 199-230.

[26] Popova, V., "Exploration of Skepticism, Client-Specific Experiences, and Audit Judgments," Managerial Auditing Journal, Vol. 28, No. 2, pp. 140-160, 2012. DOI: 10.1108/ 02686901311284540

[27] Mohd-Sanusi Z., Mohamed N., Omar N., Mohd- Nassir M.D., "Effects of Internal Controls, Fraud Motives and Experience in Assessing Likelihood of Fraud Risk," Journal of Economics, Business and Management, Vol. 3, No. 2, pp. 194-200, 2015. DOI: 10.7763/JOEBM.2015.V3.179.

[28] Herliansyah Y., Ilyas M., "Pengaruh Pengalaman Auditor Terhadap Penggunaan Bukti Tidak Relevan Dalam Auditor Judgment," Proceedings of the IX Padang National Symposium Accounting, pp. 23-26, 2006. https://akuntansi a.com/jurnal-akuntansi-sna/sna-9/3/

[29] Kiswanto and Maulana P.A., "Pengalaman Memoderasi Penilaian Resiko Kecurangan, Skeptisisme, Beban Kerja pada Kemampuan Mendeteksi Kecurangan,” Jurrnal Ilmiah Akuntansi dan Bisnis, Vol. 14, No. 2, pp. 183-195, 2019. DOI: 10.24843/ JIAB.2019.v14.i02.p04

[30] Knapp C.A., Knapp M.C., "The Effects of Experience and Explicit Fraud Risk Assessment in Detecting Fraud with Analytical Procedures," Accounting, Organizations and Society, Vol. 26, No. 1, pp. 25-37, 2001. DOI: 10.1016/S0361-3682(00)00005-2

[31] Jones M.J., "Internal Control, Accountability and Corporate Governance: Medieval and odern Britain Compared," Accounting, Auditing \& Accountability Journal, Vol. 21, No. 7, pp. 1052-1075, 2008. DOI: 10.1108/095135708109 07474

[32] Florio C., Leoni G., "Enterprise Risk Management and Firm Performance: The Italian Case," The British Accounting Review, Vol. 49, No. 1, pp. 56-74, 2017. DOI: 10.1016/ j.bar.2016.08.003

[33] Paletta A., Alimehmeti G., "SOX Disclosure and the Effect of Internal Controls on Executive Compensation," Journal of Accounting, Auditing \& Finance, Vol. 33, No. 2, pp. 277-295, 2018. DOI: $10.1177 / 0148558 X 16630445$

[34] Figueroa C.R., Cardona, R.J.C., "Does Experience Affect Auditors' Professional Judgement? Internal Controls and Fraud Decisions," In Global Conference on Business \& 
Finance Proceedings, Institute for Business \& Finance Research, Vol. 8, No. 2, pp. 221-222, 2013. https://www.theibfr.com/conference-proceedings/

[35] Siregar, Ren Adam Abdillah dan Setyaningrum, D., "Analisis Pengaruh Peran Badan Pengawasan Keuangan Pemerintah Terhadap Opini dan Temuan Audit," September 2015.https://www.researchgate.net/publication/ 332188361

[36] Bonner, S. E., "Judgement and Decision Making Research in Accounting," Accounting Horizons, Vol. 13, No. 4, pp. 385-398, 1999. DOI: 10.2308/acch.1999. 13.4.385

[37] Solomon, I., \& Trotman, K. T., "Experimental Judgment and Decision Research in Auditing: The First 25 Years of AOS," Accounting, Organizations and Society, Vol. 28, No. 4, pp. 395-412, 2003. DOI: 10.1016/S0361-3682(02)0002 3-5

[38] Pallant, J., "Preliminary Analysis: Checking the reliability of a scale," SPSS Survival Manual a Step by Step Guide to Data Analysis using the SPSS Program (4th Edition). Berkshire: Allen \& Unwin, 2011, pp. 102-107

[39] Krosnick, J. A., \& Presser, S., "Number of Points on Rating Scales," Question and Questionnaire Design. In Wright, J. D. \& Marsden, P. V., Handbook of Survey Research (2nd Edition). San Diego, CA: Elsevier, pp. 9-15, 2009 